\author{
Hanna Mizgasska \\ Państwowa Wyższa Szkoła Zawodowa im. Prezydenta Stanisława Wojciechowskiego w Kaliszu, Polska • \\ The President Stanisław Wojciechowski State University of Applied Sciences in Kalisz, Poland \\ ŁUKASZ WśCIUBIAK \\ Uniwersytet Ekonomiczny w Poznaniu, Polska - Poznań University of Economics and Business, Poland
}

\title{
Wpływ kwalifikacji właścicieli na sposób zarządzania małymi i średnimi firmami rodzinnymi
}

\section{Impact of Owners' Qualifications on the Management Style of Small and Medium Family Businesses}

\begin{abstract}
Streszczenie: Celem artykułu jest określenie związku pomiędzy poziomem wykształcenia formalnego właścicieli firm rodzinnych, ich doświadczeniem zawodowym, pracą zgodną z wyuczonym zawodem, pracą na stanowisku kierowniczym i udziałem w szkoleniach a sposobem zarządzania i finansowania ich firm. Sposób zarządzania charakteryzują cele działalności, przeznaczenie wypracowanego zysku, liczba godzin pracy w firmie oraz delegowanie zadań. Pod uwagę wzięto także stopień wykorzystania kredytów, aplikowanie o środki z funduszy UE oraz ogólne wyniki finansowe firmy. W opracowaniu wykorzystano materiał empiryczny zebrany za pomocą kwestionariusza ankietowego na celowo dobranej próbie 135 firm rodzinnych z terenu południowej Wielkopolski, reprezentujących sektor małych i średnich przedsiębiorstw. Badanie zostało przeprowadzone przez studentów drugiego roku studiów licencjackich z Państwowej Wyższej Szkoły Zawodowej w Kaliszu w ramach zajęć z przedsiębiorczości. Badanie zostało przeprowadzone w roku 2017, natomiast pozyskane informacje o działalności firm dotyczyły lat 2014-2016. Zgromadzony materiał empiryczny opracowano za pomocą metod statystyki opisowej, korelacji rang gamma oraz testu niezależności chi-kwadrat. Uzyskane wyniki wskazują na istotny statystycznie wpływ udziału przedsiębiorcy w różnych formach szkoleń na sposób zarządzania i finansowania badanych firm rodzinnych oraz uzyskiwane przez nie wyniki finansowe.
\end{abstract}

\begin{abstract}
The aim of the study is to diagnose the relationship between the level of formal education, professional experience, having a job matching the learned profession, working on a managerial position and participation in training of family business owners and their method of management. The way of management is characterised by business goals, profit allocation, number of work hours in the company and delegation of tasks. The degree of using credits and loans, applying for and using EU funds, as well as the company's financial results were also considered. Empirical material collected in a targeted manner using a survey method from 135 family companies representing the sector of small and medium-sized enterprises in southern Wielkopolska was used in the work. The survey was carried out by students of the second year of undergraduate studies at the State Higher Vocational School in Kalisz as part of a course in entrepreneurship. The research was carried out in 2017 and the information about compa-
\end{abstract}


nies concerns the years 2014-2016. The empirical material was processed by the analysis of descriptive statistics and interdependencies were examined by the gamma correlation method and the Chi-square test. The research has shown a significant impact of both industry-related and broad-based training on the way of management and financing, as well as the financial results of the surveyed family businesses.

Słowa kluczowe: firmy rodzinne; kwalifikacje; małe i średnie przedsiębiorstwa; szkolenia; zarządzanie

Keywords: family businesses; management; qualifications; small and medium-sized enterprises; training

Otrzymano: 6 maja 2019

Received: 6 May 2019

Zaakceptowano: 10 sierpnia 2019

Accepted: 10 August 2019

\section{Sugerowana cytacja/Suggested citation:}

Mizgajska, H., Wściubiak, Ł. (2019). Wpływ kwalifikacji właścicieli na sposób zarządzania małymi i średnimi firmami rodzinnymi. Przedsiębiorczość - Edukacja [Entrepreneurship - Education], 15(2), 83-94. doi: 10.24917/20833296.152.6

\section{Wstęp}

W Polsce przedsiębiorstwa rodzinne stanowią poważną część tworzącego się sektora małych i średnich przedsiębiorstw. Według raportu Instytutu Biznesu Rodzinnego, w 2014 r. firmy rodzinne stanowiły $36 \%$ wszystkich przedsiębiorstw w Polsce i wytwarzały $18 \%$ PKB (IBR, 2019). Pomimo stale rosnącej liczby nie doczekały się jednak swojego miejsca w statystyce GUS-u. Sytuacja ta może być następstwem braku jednej, uniwersalnej definicji firmy rodzinnej. Poszczególni autorzy stosują bowiem rozmaite kryteria demarkacyjne oparte na takich czynnikach, jak: własność i zarządzanie, zaangażowanie rodziny w przedsiębiorstwo czy sukcesja (Leszczewska, 2016: 29-32). W literaturze anglojęzycznej spotkać można nawet podejście, w świetle którego podstawą zakwalifikowania danego podmiotu do grona firm rodzinnych jest to, czy sam właściciel postrzega prowadzone przez siebie przedsiębiorstwo za rodzinne (Cooper, Upton, Seeman, 2005; Fernandez, Nieto, 2005; Murphy, 2005; Zahra, 2005).

Zdecydowana większość firm rodzinnych jest jednoosobowo zarządzana przez właściciela. Rola przedsiębiorcy jako lidera i właściciela małej bądź średniej firmy rodzinnej jest niewspółmiernie ważniejsza niż w dużych firmach ze względu na spłaszczoną strukturę organizacyjną. Firmy rodzinne cechuje zazwyczaj struktura zwana promienistą, co oznacza, że podejmowane decyzje muszą być akceptowane przez właściciela. Firmy rodzinne są często zarządzane w sposób autokratyczny. Z tego też względu wpływ kwalifikacji właściciela firmy rodzinnej na sposób zarządzania jest większy niż w pozostałych przedsiębiorstwach.

W literaturze przedmiotu podnoszona jest także kwestia specyficznego charakteru decyzji finansowych podejmowanych w firmach rodzinnych (Winnicka-Popczyk, 2008). Decyzje te mogą dotyczyć zarówno wyboru źródeł finansowania, podejmowania przedsięwzięć inwestycyjnych, jak i sposobu podziału wypracowanego zysku. Zauważa się przy tym, że logika finansowa firm rodzinnych w znacznej mierze uzależniona jest od norm wyznawanych przez daną rodzinę oraz charakterystyki samego właściciela 
(Motylska-Kuźma, 2019). Oznacza to, że poziom kwalifikacji przedsiębiorcy może mieć znaczący wpływ na podejmowane przez niego decyzje finansowe.

Celem niniejszego artykułu jest określenie związku pomiędzy poziomem kwalifikacji właścicieli a sposobem zarządzania i finansowania badanych firm rodzinnych. Główną tezą pracy jest stwierdzenie, że kwalifikacje właścicieli wpływają na sposób zarządzania i finansowania oraz wyniki firm rodzinnych, co przyczynia się do ich rozwoju. W opracowaniu wykorzystano wyniki badań przeprowadzonych w 2017 r. na celowo dobranej próbie 135 firm rodzinnych $\mathrm{z}$ terenu południowej Wielkopolski.

\section{Kwalifikacje przedsiębiorcy w świetle literatury przedmiotu}

Wśród badaczy zajmujących się problematyką przedsiębiorczości panuje daleko idąca zgodność, że kompetencje właściciela-przedsiębiorcy stanowią istotny czynnik wpływający na poziom konkurencyjności, perspektywy rozwojowe oraz wyniki małych i średnich przedsiębiorstw (Man, Lau, Snape, 2008; Tehseen, Ramayah, 2015). W zaproponowanym przez J. Wasilczuk modelu rozwoju małego i średniego przedsiębiorstwa kompetencje właściciela stanowią kluczowy element, wpływający na sposób postrzegania szans i zagrożeń tkwiących w otoczeniu, możliwości rozwoju przedsiębiorstwa oraz uzyskiwane efekty. W świetle powyższego modelu kompetencje przedsiębiorcy przekładają się także na cele i strategię przedsiębiorstwa oraz sposób zarządzania nim (Lisowska, 2013).

Zasadniczym problemem pozostaje jednak fakt, że pomimo panującego konsensusu co do znaczenia kompetencji przedsiębiorczych, pojęcie to jest postrzegane i definiowane przez poszczególnych autorów w sposób odmienny (zob. np. Mitchelmore, Rowley, 2010; Morris i in., 2013). D. Piróg (2015: 368) zwraca uwagę na postępującą ewolucję pojęcia kompetencji przedsiębiorczych, przy czym jako cechę wspólną wszystkich propozycji podaje odniesienie do wybranych obszarów wiedzy, umiejętności i postaw. Zasadnicze różnice dotyczą natomiast znaczenia, jakie poszczególni autorzy przypisują poszczególnym obszarom kompetencji.

B. Glinka i S. Gudkova (2011: 122-123) wyróżniają pięć zasadniczych elementów kompetencji przedsiębiorczych, które prowadzą do założenia, przetrwania oraz rozwoju przedsiębiorstwa. Są to: cechy osobowe przedsiębiorcy, mechanizmy poznawcze, motywy działania, poczucie własnej skuteczności oraz wiedza ogólna i wiedza specjalistyczna. Przywoływane autorki zwracają przy tym uwagę na fakt, że poszczególne składniki kompetencji są $\mathrm{w}$ różnym stopniu podatne na zmiany. Zdecydowanie największa trudność związana jest ze zmianą cech osobowych przedsiębiorcy, co może wiązać się z koniecznością ingerencji w trwałe konstrukcje ludzkiej psychiki. Najłatwiej natomiast ulegają zmianom posiadane przez przedsiębiorcę zasoby wiedzy.

Zwolennikiem szerokiego ujęcia kompetencji przedsiębiorczych jest z kolei J. Korpysa (2013: 169-171), który uważa, że współczesny przedsiębiorca powinien nie tylko odznaczać się odpowiednimi cechami (takimi jak: kreatywność, motywacja do działania, zdolność do przezwyciężania niepewności) i kompetencjami społecznymi, ale także posiadać odpowiednie wykształcenie, doświadczenie zawodowe oraz umiejętności w zakresie zarządzania zmianą, tworzenia strategii biznesowych czy też rozpoznawanie i wykorzystywania sposobności biznesowych.

Wyniki dotychczasowych badań pokazują, że poziom kapitału ludzkiego, związanego z osobą przedsiębiorcy, jest pozytywnie skorelowany z przeżywalnością i wzrostem firm 
(Unger i in., 2011). Podobny pogląd prezentuje także A. Kamińska (2011: 33), która zauważa, że przedsiębiorstwo ma większe szanse na przeżycie i szybki wzrost, jeśli jego założyciel legitymuje się wyższym wykształceniem, ma doświadczenie w danej branży oraz w pracy na stanowisku kierowniczym, a także wywodzi się z rodziny z tradycjami biznesowymi. Należy przy tym zauważyć, że kapitał ludzki przedsiębiorcy może mieć także pośredni wpływ na wyniki firmy. Przykładowo, wykształcenie przedsiębiorcy może być czynnikiem ułatwiającym przezwyciężenie barier finansowych (Parker, van Praag, 2006) bądź też pozyskiwanie wysoko wykwalifikowanych pracowników - szczególnie w początkowej fazie działalności firmy (Bublitz i in., 2018).

Badania dotyczące wpływu kompetencji przedsiębiorczych na działalność przedsiębiorstw napotykają na poważny problem, dotyczący obiektywnego pomiaru niektórych ich elementów (np. cech charakterologicznych czy też prezentowanych przez przedsiębiorców postaw). Pewnym rozwiązaniem powyższego problemu może być zawężenie zakresu przedmiotowego prowadzonych badań wyłącznie do kwalifikacji przedsiębiorcy, których wyznacznikami są posiadane przez niego zasoby wiedzy (zdobyte zarówno $\mathrm{w}$ trakcie odbytej edukacji, jak i przez różne formy doskonalenia zawodowego, w tym przede wszystkim szkolenia) oraz dotychczasowe doświadczenie zawodowe.

Należy podkreślić, że choć literatura przedmiotu podejmująca problem kompetencji przedsiębiorcy jest już dość obszerna, to w dalszym ciągu można odczuć pewien niedosyt wynikający z braku opracowań odnoszących się właśnie do kwestii kwalifikacji przedsiębiorcy. Dodatkowo, większość $\mathrm{z}$ istniejących prac z tego zakresu dotyczy przedsiębiorstw znajdujących się na początkowym etapie swojej działalności.

\section{Metodyka badań}

W toku postępowania badawczego podjęto się próby udzielenia odpowiedzi na następujące pytania badawcze:

- Czy istnieje związek pomiędzy wykształceniem formalnym, udziałem w szkoleniach, stażem pracy i pracą zgodną $\mathrm{z}$ wyuczonym zawodem a poszczególnymi celami działalności firmy, takimi jak: osiąganie zysku w długim lub krótkim czasie, wzrost firmy oraz uzyskiwanie osobistej satysfakcji przez przedsiębiorcę?

- Czy istnieje związek pomiędzy wykształceniem formalnym, udziałem w szkoleniach, stażem pracy i pracą zgodną z wyuczonym zawodem a delegowaniem zadań oraz liczbą godzin spędzonych przez przedsiębiorcę w firmie?

- Czy istniej związek pomiędzy wykształceniem formalnym, udziałem w szkoleniach, stażem pracy i pracą zgodną z wyuczonym zawodem a korzystaniem z kredytów, finansowaniem ze środków UE oraz wynikiem finansowym firmy?

- Który z elementów decydujących o poziomie kwalifikacji przedsiębiorcy najsilniej wpływa na sposób zarządzania i finansowania firmy rodzinnej?

Weryfikacji poddano następujące hipotezy badawcze:

- H1. Istnieje zależność pomiędzy poziomem kwalifikacji właściciela a sposobem zarządzania firmą rodzinną.

- H2. Istnieje zależność pomiędzy poziomem kwalifikacji właściciela a sposobem finansowania firmy rodzinnej.

Przez kwalifikacje rozumie się stopień wykształcenia formalnego, udział w szkoleniach oraz posiadane doświadczenie zawodowe. Doświadczenie zawodowe to staż pracy, 
praca zgodna z wyuczonym zawodem oraz praca na stanowisku kierowniczym przed założeniem firmy rodzinnej.

Sposób zarządzania przedsiębiorstwem charakteryzują m.in. cele działalności, przeznaczenie wypracowanego zysku, liczba godzin spędzanych przez właściciela $\mathrm{w}$ firmie czy też stopień delegowania zadań. Za najważniejsze wyznaczniki sposobu finansowania działalności badanych firm rodzinnych przyjęto stopień wykorzystania kredytów oraz aplikowanie o środki z funduszy UE. Oceny wyników finansowych badanych przedsiębiorstw dokonano na podstawie deklarowanego przez respondentów stopnia zadowolenia z wypracowanego zysku oraz płynności finansowej firmy.

Do pomiaru poszczególnych zmiennych wykorzystano wielostopniowe skale porządkowe (np. w przypadku poziomu wykształcenia formalnego - stopień zadowolenia z osiągniętego zysku itp.) bądź też zoperacjonalizowano je jako zmienne binarne, przyjmujące wartość 1 , gdy dane zjawisko występuje (np. doświadczenie na stanowisku kierowniczym przed założeniem firmy, praca zgodna $\mathrm{z}$ wyuczonym zawodem, udział w szkoleniach, wykorzystanie środków z funduszy UE itp.) lub wartość 0 , gdy zjawisko nie występuje. W celu weryfikacji postawionych hipotez zbadano zależności pomiędzy wskaźnikami opisującym kwalifikacje przedsiębiorcy a poszczególnymi zmiennymi odnoszącymi się do sposobu zarządzania i finansowania firmy. Dokonano tego za pomocą rachunku korelacji rang gamma oraz testu niezależności chi-kwadrat. Za istotne statystycznie zależności uznano tylko te wyniki, które udało się potwierdzić za pomocą obu tych testów na poziomie $\mathrm{p}<0,05$.

Badanie przeprowadzono w 2017 r. na celowo dobranej próbie 135 małych i średnich firm rodzinnych $\mathrm{z}$ terenu południowej części województwa wielkopolskiego. Materiał empiryczny został zebrany w formie wywiadów bezpośrednich z wykorzystaniem narzędzia w postaci kwestionariusza ankietowego przez odpowiednio poinstruowanych studentów studiów licencjackich Państwowej Wyższej Szkoły Zawodowej w Kaliszu.

Dla potrzeb prowadzonych badań przyjęto, że przedsiębiorstwem rodzinnym jest każda firma założona oraz prowadzona $\mathrm{z}$ intencją zachowania jej rodzinnego charakteru. Takie podejście wydaje się uzasadnione ze względu na specyfikę uwarunkowań polskiej gospodarki oraz wielkość badanych podmiotów. W Polsce mamy bowiem do czynienia $\mathrm{z}$ przedsiębiorstwami, które z reguły zostały założone stosunkowo niedawno (tj. najdalej w latach 90. XX w.) i są zarządzane przez pierwsze pokolenie właścicieli. Warto przy tym zauważyć, że podobną definicję firmy rodzinnej można spotkać m.in. w pracach R.A. Litza (1995) oraz P. Sharmy (2004).

\section{Charakterystyka badanych przedsiębiorstw}

Wśród badanych podmiotów zdecydowanie dominowały przedsiębiorstwa mikro (69\%) oraz małe (24\%), zaś jako przedmiot prowadzonej działalności najczęściej wskazywano usługi (42\%), handel (24\%) oraz przemysł (18\%). Blisko połowa badanych firm została założona na terenach wiejskich (46\%), dość licznie (22\%) reprezentowane były także przedsiębiorstwa działające w małych miastach (do 20 tys. mieszkańców). Zakładanie firm rodzinnych $\mathrm{w}$ mniejszych miejscowościach wynika często z trudnego rynku pracy oraz chęci zapewnienia warsztatu pracy dla całej rodziny.

Zdecydowana większość przedsiębiorstw (95\%) została założona przez obecnych właścicieli, natomiast zaledwie w co dwudziestym przypadku doszło do sukcesji 
międzypokoleniowej. Środki na założenie biznesu rodzinnego pochodziły nie tylko z zasobów własnych przedsiębiorcy $(57,8 \%)$, ale także z zaciągniętego kredytu bankowego (18\%), wsparcia ze strony rodziny $(16,2 \%)$ oraz dofinansowania ze środków UE $(1,4 \%)$. Przed podjęciem własnej działalności gospodarczej 74\% właścicieli pracowało w innej firmie, $10 \%$ kształciło się, a tylko 5,5\% było bezrobotnych. Wyniki badań potwierdzają zatem, że bezrobocie jako czynnik wpływający na decyzje o założeniu firmy ma niewielkie znaczenie. Poziom wykształcenia właścicieli badanych firma można uznać za dość wysoki, gdyż $45 \%$ z nich posiadało średnie wykształcenie, a 30\% - wykształcenie wyższe.

Przed założeniem firmy ponad połowa badanych (55\%) wykonywała pracę nie związaną z podjętą później działalnością gospodarczą, zaś tylko jedna trzecia (32\%) przedsiębiorców miała doświadczenie kierownicze. Brak doświadczenia zawodowego właściciele badanych firm starali się uzupełnić przez udział w szkoleniach branżowych, przeznaczając na to w analizowanym okresie (lata 2014-2016) przeciętnie 7 dni. Znacznie mniej czasu przeznaczano natomiast na udział w szkoleniach z zakresu zarządzania (1,5 dnia), księgowości (0,9 dnia) czy wykorzystania środków z Unii Europejskiej (0,5 dnia).

Średni wiek właścicieli badanych firm rodzinnych wynosił 48 lat. Oznacza to, że większość przedsiębiorców ma przed sobą jeszcze przynajmniej kilkunastoletni okres aktywności zawodowej. Tym niemniej już teraz powinni oni myśleć o przygotowaniu odpowiednich planów sukcesyjnych. Problem ten wydaje się być szczególnie aktualny w kontekście starzejącej się populacji polskich przedsiębiorstw. O ile bowiem w roku 2010 podmioty działające na rynku powyżej 20 lat stanowiły $20 \%$ ogółu przedsiębiorstw, o tyle już w roku 2015 udział ten zwiększył się do 37\% (Mączyńska, 2016). Zdaniem przywoływanej autorki, większość polskich przedsiębiorstw nie jest przygotowana do sukcesji, gdyż 60\% firm rodzinnych nie podjęło żadnych przygotowań w tym względzie. Szczególnie niepokojący jest fakt, że większość przedsiębiorców zdaje się nie doceniać ogromu wyzwań związanych z międzypokoleniowym transferem władzy i własności w firmie.

\section{Wyniki badań}

Jako cel działalności firmy ankietowani przedsiębiorcy najczęściej wskazywali jej wzrost (32\%), osiąganie zysków w długim czasie (31\%) oraz osobistą satysfakcję (25\%). Osiąganie krótkookresowych zysków było natomiast celem $12 \%$ badanych. Wypracowany przez firmę zysk był najczęściej reinwestowany w jej rozwój, tzn. przeznaczany na zakup środków trwałych (39\%), bądź też na powiększenie stanu aktywów obrotowych, niezbędnych do zwiększenia przychodów ze sprzedaży w przyszłości (33\%). W niemal co piątym przypadku (19\%) zysk przeznaczano na konsumpcję, natomiast inwestycji poza firmą dokonywało $10 \%$ badanych.

Badani przedsiębiorcy spędzali średnio 10 godz. dziennie w swojej firmie. Należy przy tym podkreślić, że dość chętnie stosowali oni styl zarządzania oparty na delegowaniu zadań pracownikom: $50 \%$ respondentów czyniło to często, $40 \%$ sporadycznie i tylko $10 \%$ badanych nie korzystało z możliwości delegowania zadań.

Rozpatrując kwestię sposobu finansowania badanych przedsiębiorstw, należy zauważyć, że w latach 2014-2016 z kredytów bankowych skorzystało 39\% respondentów. Rezultat ten jest zgodny z ustaleniami zawartymi w raporcie PARP (PARP, 2018), w świetle których małe przedsiębiorstwa finansują swoją działalność inwestycyjną głównie ze środków własnych (60\%) oraz z kredytów i pożyczek (20\%). 
Spośród badanych firm w latach 2014-2016 o fundusze UE ubiegało się 16\% respondentów, a w zdecydowanej większości przypadków (83\%) starania te zostały uwieńczone sukcesem. Przedsiębiorstwa, które nie korzystały z możliwości aplikowania o środki UE, jako przyczyny tej decyzji najczęściej wskazywały: brak potrzeby otrzymania takiej formy wsparcia (40\%), brak wystarczających informacji (24\%), brak wiary w otrzymanie dofinansowania (22\%) oraz trudności z wypełnieniem wniosku (10\%).

Należy podkreślić, że zdecydowana większość przedsiębiorstw objętych niniejszym badaniem znajdowała się w dobrej kondycji ekonomicznej, co jest odzwierciedleniem korzystnej sytuacji polskich przedsiębiorstw obserwowanej w latach 2008-2016 (PARP, 2018). W latach 2014-2016 wzrost sprzedaży odnotowało 60\% respondentów, natomiast nieco ponad połowie badanych (51\%) udało się w analogicznym okresie osiągnąć także poprawę wyniku finansowego. Większość właścicieli badanych firm rodzinnych była zadowolona $\mathrm{z}$ osiągniętego zysku w stopniu dobrym (38\%) lub średnim (43\%). Wyższy poziom zadowolenia respondentów odnotowano w odniesieniu do płynności finansowej firmy: 58\% badanych oceniało ją jako dobrą, a 35\% - jako średnią.

Jak już wspomniano wcześniej, weryfikacji postawionych hipotez badawczych dokonano na podstawie zależności pomiędzy wskaźnikami opisującym kwalifikacje przedsiębiorcy a poszczególnymi zmiennymi odnoszącymi się do sposobu zarządzania i finansowania firmy. W tym celu wykorzystano rachunek korelacji rang gamma oraz test niezależności chi-kwadrat, a za istotne statystycznie uznano tylko te zależności, które udało się potwierdzić za pomocą obu wymienionych testów na poziomie $\mathrm{p}<0,05$. Uzyskane wyniki przedstawiono w dalszej części niniejszego opracowania. Ze względów natury praktycznej zrezygnowano z prezentacji wyników, których statystyczna istotność nie została potwierdzona w toku prowadzonych analiz.

Najważniejszym elementem kwalifikacji badanych przedsiębiorców, mającym znaczący wpływ na sposób zarządzania i finansowania firm rodzinnych, okazał się udział w szkoleniach (tabela 1 ).

Tabela 1. Kwalifikacje właścicieli a sposób zarządzania i finansowania firm rodzinnych $(\mathrm{p}<0,05)$

\begin{tabular}{|l|l|c|c|c|}
\hline \multicolumn{1}{|c|}{ Kwalifikacje } & \multicolumn{1}{|c|}{$\begin{array}{c}\text { Elementy sposobu zarządzania } \\
\text { lub finansowania firmy }\end{array}$} & N & Gamma & $\mathbf{C h i}^{\wedge} \mathbf{2}$ \\
\hline $\begin{array}{l}\text { Poziom wykształcenia } \\
\text { formalnego }\end{array}$ & $\begin{array}{l}\text { Brak potrzeby ubiegania się } \\
\text { o fundusze UE }\end{array}$ & 135 & $-0,201$ & $\begin{array}{c}6,256 \\
(\mathrm{df}=2)\end{array}$ \\
\hline $\begin{array}{l}\text { Prowadzenie biznesu } \\
\text { zgodne z wyuczonym } \\
\text { zawodem }\end{array}$ & $\begin{array}{l}\text { Zysk przeznaczono na zakup } \\
\text { środków trwałych }\end{array}$ & 135 & 0,422 & $\begin{array}{c}6,340 \\
(\mathrm{df}=1)\end{array}$ \\
\hline $\begin{array}{l}\text { Prowadzenie biznesu } \\
\text { zgodne z wyuczonym } \\
\text { zawodem }\end{array}$ & $\begin{array}{l}\text { Otrzymano dofinansowanie } \\
\text { z funduszy UE }\end{array}$ & 131 & 0,489 & $\begin{array}{c}4,241 \\
(\mathrm{df}=1)\end{array}$ \\
\hline $\begin{array}{l}\text { Doświadczenie zawodowe } \\
\text { przed założeniem firmy }\end{array}$ & Zysk przeznaczono na konsumpcję & 128 & 0,338 & $\begin{array}{c}9,724 \\
(\mathrm{df}=2)\end{array}$ \\
\hline $\begin{array}{l}\text { Bycie bezrobotnym przed } \\
\text { założeniem firmy }\end{array}$ & Korzystanie z kredytów & 117 & $-0,426$ & $\begin{array}{c}5,363 \\
(\mathrm{df}=1)\end{array}$ \\
\hline $\begin{array}{l}\text { Udział w szkoleniach } \\
\text { ogółem }\end{array}$ & Celem działalności był wzrost firmy & 135 & 0,351 & $\begin{array}{c}4,011 \\
(\mathrm{df}=1)\end{array}$ \\
\hline
\end{tabular}




\begin{tabular}{|l|l|c|c|c|}
\hline $\begin{array}{l}\text { Udział w szkoleniach } \\
\text { ogółem }\end{array}$ & $\begin{array}{l}\text { Zysk przeznaczono na zakup } \\
\text { środków trwałych }\end{array}$ & 135 & 0,507 & $\begin{array}{c}9,406 \\
(\mathrm{df}=1)\end{array}$ \\
\hline $\begin{array}{l}\text { Udział w szkoleniach } \\
\text { ogółem }\end{array}$ & Wzrost wyniku finansowego firmy & 135 & 0,355 & $\begin{array}{c}4,218 \\
(\mathrm{df}=1)\end{array}$ \\
\hline $\begin{array}{l}\text { Udział w szkoleniach } \\
\text { ogółem }\end{array}$ & $\begin{array}{l}\text { Brak informacji jako przyczyna } \\
\text { nieubiegania się o fundusze UE }\end{array}$ & 135 & $-0,480$ & $\begin{array}{c}6,639 \\
(\mathrm{df}=1)\end{array}$ \\
\hline
\end{tabular}

Źródło: badania własne

Udział w szkoleniach jest pozytywnie skorelowany ze wzrostem firmy jako celem działalności. W grupie osób biorących udział w szkoleniach odsetek respondentów, którzy jako cel działalności prowadzonej firmy wskazywali jej wzrost, wynosił aż 52\%. Ponadto dwie trzecie (67\%) przedsiębiorców podnoszących swoje kwalifikacje przez uczestnictwo w szkoleniach decydowały się także na przeznaczenie wypracowanego zysku na zakup środków trwałych. Wśród przedsiębiorstw zarządzanych przez takie osoby odnotowano także nieco wyższy odsetek podmiotów (58\%), których wynik finansowy wzrósł w badanym okresie.

Innym czynnikiem, który okazał się mieć wpływ na sposób zarządzania firmą, była zgodność prowadzonej działalności z profilem wykształcenia przedsiębiorcy. Wśród respondentów pracujących zgodnie $\mathrm{z}$ wyuczonym zawodem odnotowano bardzo wysoki odsetek osób (69\%) deklarujących przeznaczenie wypracowanego zysku na zakup środków trwałych. Zbieżność profilu działalności firmy z wykształceniem przedsiębiorcy wpływała także na efektywność wnioskowania o środki UE. Przedsiębiorstwa te częściej od pozostałych podmiotów otrzymywały bowiem tego rodzaju dofinansowania.

Udział w szkoleniach właścicieli firm rodzinnych jest pozytywnie skorelowany ze wzrostem firmy jako celem prowadzonej działalności, przeznaczaniem zysku na zakup środków trwałych oraz ze wzrostem firmy. Przedsiębiorcy dbający o podnoszenie kwalifikacji przejawiają zatem większą troskę o perspektywy rozwojowe prowadzonej firmy i są nastawieni na odniesienie trwałego, długookresowego sukcesu w biznesie.

Badanie nie wykazało bezpośredniego związku między wykształceniem formalnym a sposobem zarządzania firmą. Wykształcenie ma natomiast pośredni wpływ na sposób finansowania firmy, związany $\mathrm{z}$ aplikowaniem o środki UE. Wraz ze wzrostem poziomu wykształcenia respondentów zmniejsza się bowiem odsetek osób uzasadniających rezygnację z ubiegania się o fundusze UE brakiem potrzeby uzyskania takiego dofinansowania.

Przedsiębiorcy mający status osoby bezrobotnej przed założeniem własnej firmy zdecydowanie rzadziej korzystali z kredytów jako formy finansowania prowadzonej działalności. Bezrobocie uważane jest za negatywny motyw zakładania własnej firmy, a wyniki badań wskazują, że tego rodzaju przedsiębiorstwa charakteryzują się niższą stopą przeżywalności w porównaniu z pozostałymi podmiotami (Millan, Congergado, Roman, 2014). Z kolei długość doświadczenia zawodowego przedsiębiorcy okazała się być związania $z$ deklarowanym przeznaczeniem zysku na konsumpcję. Oznacza to, że wraz ze wzrostem długości stażu pracy wzrastał udział właścicieli skłonnych przeznaczać wypracowany przez firmę zysk na bieżące potrzeby konsumpcyjne.

Zaprezentowane powyżej rezultaty potwierdziły wpływ udziału właścicieli w szkoleniach na sposób zarządzania i finansowania prowadzonych przez nich firm rodzinnych. Należy jednak zauważyć, że respondenci deklarowali uczestnictwo w wielu różnorodnych formach szkoleń (m.in. branżowych, z zakresu zarządzania, księgowości i finansów, 
a także związanych z aplikowaniem o środki UE), które w odmienny sposób mogą kształtować postawy właściciela oraz podejmowane przez niego decyzję. Dlatego też kwestia ta była również przedmiotem prowadzonych analiz (tabela 2 ).

Tabela 2. Udział właścicieli w różnych formach szkolenia a sposób zarządzania i finansowania firm rodzinnych $(\mathrm{p}<0,05)$

\begin{tabular}{|l|l|c|c|c|}
\hline \multicolumn{1}{|c|}{ Kwalifikacje } & \multicolumn{1}{|c|}{$\begin{array}{c}\text { Elementy sposobu zarządzania } \\
\text { lub finansowania firmy }\end{array}$} & N & Gamma & Chi^2 \\
\hline $\begin{array}{l}\text { Udział w szkoleniach } \\
\text { branżowym }\end{array}$ & $\begin{array}{l}\text { Zysk przeznaczono na zakup } \\
\text { środków trwałych }\end{array}$ & 135 & 0,476 & $\begin{array}{c}8,446 \\
(\mathrm{df}=1)\end{array}$ \\
\hline $\begin{array}{l}\text { Udział w szkoleniach } \\
\text { z zakresu zarządzania }\end{array}$ & $\begin{array}{l}\text { Brak informacji jako przyczyna } \\
\text { nieubiegania się o środki z UE }\end{array}$ & 135 & $-0,640$ & $\begin{array}{c}6,413 \\
(\mathrm{df}=1)\end{array}$ \\
\hline $\begin{array}{l}\text { Udział w szkoleniach } \\
\text { z zakresu księgowości }\end{array}$ & Celem działalności był wzrost firmy & 135 & 0,543 & $\begin{array}{c}3,578 \\
(\mathrm{df}=1)\end{array}$ \\
\hline $\begin{array}{l}\text { Udział w szkoleniach } \\
\text { z zakresu księgowości }\end{array}$ & Delegowanie zadań innej osobie & 135 & 0,551 & $\begin{array}{c}5,533 \\
(\mathrm{df}=1)\end{array}$ \\
\hline $\begin{array}{l}\text { Udział w szkoleniach } \\
\text { z zakresu funduszy UE }\end{array}$ & $\begin{array}{l}\text { Ubieganie się o wsparcie z funduszy } \\
\text { UE }\end{array}$ & 135 & 0,681 & $\begin{array}{c}5,148 \\
(\mathrm{df}=1)\end{array}$ \\
\hline $\begin{array}{l}\text { Udział w szkoleniach } \\
\text { z zakresu funduszy UE }\end{array}$ & $\begin{array}{l}\text { Otrzymanie dofinansowania } \\
\text { z funduszy UE }\end{array}$ & 135 & 0,699 & $\begin{array}{c}11,926 \\
(\mathrm{df}=1)\end{array}$ \\
\hline $\begin{array}{l}\text { Udział w szkoleniach } \\
\text { z zakresu funduszy UE }\end{array}$ & $\begin{array}{l}\text { Brak informacji jako przyczyna } \\
\text { nieubiegania się o fundusze UE }\end{array}$ & 135 & $-0,640$ & $\begin{array}{c}4,565 \\
(\mathrm{df}=1)\end{array}$ \\
\hline $\begin{array}{l}\text { Udział w szkoleniach } \\
\text { z zakresu funduszy UE }\end{array}$ & $\begin{array}{l}\text { Przyczyną nieubiegania się jest brak } \\
\text { wiary w pozyskanie funduszy }\end{array}$ & 135 & $-0,611$ & $\begin{array}{c}3,934 \\
(\mathrm{df}=1)\end{array}$ \\
\hline
\end{tabular}

Źródło: badania własne

Właściciele, którzy brali udział w szkoleniach branżowych, częściej deklarowali przeznaczenie zysku na zakup środków trwałych. Z kolei udział właścicieli w szkoleniach z zakresu księgowości i finansów okazał się być powiązany z deklarowanym celem, jakim był wzrost firmy, oraz częstym delegowaniem zadań innej osobie.

Udział w szkoleniach dotyczących pozyskiwania środków UE ma związek z aplikowaniem oraz uzyskiwaniem takich funduszy. Oznacza to, że odbycie szkoleń z zakresu funduszy UE wpływa na decyzję dotyczącą ubiegania się o środki UE oraz na efektywność pozyskania tego rodzaju dofinansowań. Z kolei wraz ze wzrostem liczby respondentów deklarujących udział w szkoleniach z zakresu zarządzania zmniejsza się udział osób uzasadniający rezygnację z ubiegania się o fundusze UE brakiem należytej informacji.

Wyniki badań mają szczególnie znaczenie przede wszystkim z powodu małego doświadczenia menedżerskiego oraz zawodowego badanej grupy respondentów. Tylko jedna trzecia ankietowanych miała doświadczenie wyniesione z pracy na stanowisku kierowniczym, natomiast $45 \%$ badanych prowadzi firmę o profilu niezgodnym $\mathrm{z}$ wyuczonym zawodem.

\section{Podsumowanie}

W toku przeprowadzonych badań słuszność postawionych hipotez została potwierdzona w sposób częściowy. Częściowy, ponieważ hipotezy te udało się zweryfikować tylko w odniesieniu do niektórych wyznaczników kwalifikacji właścicieli badanych firm rodzinnych. 
Badanie wykazało, że na podejmowanie decyzji dotyczących sposobu zarządzania i finansowania firm rodzinnych duży wpływ ma udział zarówno w szkoleniach z zakresu zarządzania, jak i w szkoleniach branżowych, związanych z poszerzaniem wiedzy specjalistycznej oraz podnoszeniem kompetencji zawodowych.

Chociaż właściciele badanych firm charakteryzowali się dość wysokim poziomem wykształcenia, to jednak brakowało im doświadczenia kierowniczego oraz specjalistycznej wiedzy branżowej. Badania wykazały, że wykształcenie formalne, doświadczenie kierownicze oraz długość dotychczasowego stażu pracy (wyrażająca zakumulowane doświadczenie zawodowe) nie wpływają bezpośrednio na sposób zarządzania i finansowania firmy rodzinnej.

Przedstawione wyniki badań nie są wolne od ograniczeń. Liczebność próby (135 firm) oraz sposób jej doboru (podmioty pochodzące z terenu tylko jednego województwa) nie uprawniają do wyciągania wniosków dotyczących ogółu przedsiębiorstw rodzinnych w Polsce. Ze względu na wagę problemu, związanego ze stosunkowo rzadko podejmowaną problematyką zarządzania firmami rodzinnymi, godne rozważenia jest podjęcie podobnych badań w skali całego kraju. Zasadne wydaje się także poszerzenie zakresu przedmiotowego takich badań, np. o style i strategie zarządzania oraz bardziej wszechstronne spojrzenie na kwestię wyników ekonomiczno-finansowych firm.

Uzyskane wyniki badań mają znaczenie praktyczne. Przedstawione w niniejszym opracowaniu rezultaty mogą być wykorzystane przez instytucje odpowiedzialne za edukację, stowarzyszenia branżowe, ośrodki szkoleniowo-doradcze, a także decydentów politycznych odpowiedzialnych za kształtowanie instrumentów wsparcia sektora MŚP w Polsce. Instytucje wspierające biznes powinny rozważyć rozszerzenie swojej oferty o szkolenia adresowane do małych firm rodzinnych. Programy takich szkoleń powinny uwzględniać specyfikę firm rodzinnych i obejmować zagadnienia związane z problemami sukcesji, strategią rozwoju czy finansowania.

Literatura

References

Bublitz, E., Nielsen, K., Noseleit, F., Timmermans, B. (2018). Entrepreneurship, human capital, and labor demand: a story of signaling and matching. Industrial and Corporate Change, 27(2), 269-287.

Cooper, M., Upton, N., Seaman, S. (2005). Customer relationship management: a comparative analysis of family and nonfamily business practices. Journal of Small Business Management, 43(3), 242-256.

Fernandez, Z., Nieto, M. (2005). Internationalization strategy of small and medium- sized family businesses: some influential factors. Family Business Review, 18(1), 77-89.

Glinka, B., Gudkova, S. (2011). Przedsiębiorczość. Warszawa: Wolters Kluver Polska.

IBR (2019, 4 kwietnia). Firma rodzinna to marka. Raport $z$ badania przeprowadzonego $w$ ramach projektu „Statystyka firm rodzinnych”. Poznań. Pozyskano z: https://www.sig.org.pl/edc_media/List/ Item-477/TinyFiles/Firma-rodzinna-to-marka.pdf

Kamińska, A. (2011). Regionalne determinanty rozwoju małych i średnich przedsiębiorstw. Warszawa: Wydawnictwo Difin.

Korpysa, J. (2013). Kompetencje przedsiębiorcze właścicieli MŚP. Przedsiębiorczość i Zarządzanie, $X I V(3), 169-178$.

Leszczewska, K. (2016). Przedsiębiorstwo rodzinne: specyfika modeli biznesu. Warszawa: Wydawnictwo Difin.

Lisowska, R. (2013). Zarządzanie rozwojem małych i średnich przedsiębiorstw w obszarach zmarginalizowanych. Łódź: Wydawnictwo Uniwersytetu Łódzkiego. 
Litz, R.A. (1995). The family business: toward definitional clarity. Family Business Review, 8(2), 71-81.

Man, T., Lau, T., Snape, E. (2008). Entrepreneurial Competencies and the Performance of Small and Medium Enterprises: An Investigation through a Framework of Competitiveness. Journal of Small Business and Entrepreneurship, 21(3), 257-276.

Mączyńska, M. (2016). Firmy rodzinne. Nowa odkryta sita polskiej gospodarki. Raport sektora o stanie MSP $w$ Polsce, Warszawa: PARP.

Millan, J.E., Congregado, E., Roman, C. (2014). Entrepreneurship persistence with and without personnel: The role of human capital and previous unemployment. International Entrepreneurship and Management Journal, 10(1), 187-206.

Mitchelmore, S., Rowley, J. (2010). Entrepreneurial competencies: a literature review and development agenda. International Journal of Entrepreneurial Behaviour \& Research, 16(2), 92-111.

Morris, M.H., Webb, J.W., Fu, J., Singhai, S. (2013). A Competency-Based Perspective on Entrepreneurship Education: Conceptual and Empirical Insights. Journal of Small Business Management, 51(3), 352369.

Motylska-Kuźma, A. (2019). Logika finansowa firm rodzinnych. W: K. Safin, I. Koładkiewicz (red.), Zarządzanie firmą rodzinną: kluczowe wyzwania. Warszawa: Wydawnictwo Poltext, 231-248.

Murphy, D. (2005). Understanding the complexities of private family firms: an empirical investigation. Family Business Review, 18(2), 123-133.

Parker, S.C., van Praag, C.M. (2006). Schooling, capital constraints, and entrepreneurial performance. Journal of Business and Economic Statistics, 24(4), 416-431.

PARP (2018). Raport o stanie sektora małych i średnich przedsiębiorstw w Polsce. Warszawa.

Piróg, D. (2015). Kompetencje z zakresu przedsiębiorczości: rozważania teoretyczne i ich ilustracja w obszarze szkolnictwa wyższego. Przedsiębiorczość - Edukacja, 11, 364-376.

Sharma, P. (2004). An overview of the fields of family business studies: Current Status and Directions for the Future. Family Business Review, 17(1), 1-36.

Tehseen, S., Ramayah, T. (2015). Entrepreneurial Competencies and SMEs Business Success: The Contingent Role of External Integration. Mediterranean Journal of Social Sciences, 6(1), 50-61.

Unger, J.M., Rauch, A., Frese, M., Rosenbusch, N. (2011). Human capital and entrepreneurial success: a meta-analytical review. Journal of Business Venturing, 26(3), 341-358.

Winnicka-Popczyk, A. (2008). Specyficzne problemy zarządzania finansami w przedsiębiorstwach rodzinnych - wnioski ze studiów literaturowych oraz dotychczasowych badań. Przegląd Organizacji, 3, $39-43$.

Zahra, S. (2005). Entrepreneurial risk taking in family firms. Family Business Review, 18(1), 23-40.

Hanna Mizgajska, dr hab. inż., profesor nadzwyczajny Państwowej Wyższej Szkoły Zawodowej im. Prezydenta Stanisława Wojciechowskiego w Kaliszu, Wydział Nauk Społecznych i Humanistycznych. Jest autorką ponad 100 publikacji, głównie z zakresu ekonomiki i funkcjonowania małych i średnich przedsiębiorstw, w tym trzech monografii. Uczestniczyła w kilkunastu konferencjach międzynarodowych organizowanych przez European Foundation for Management Development (EFMD) oraz International Council for Small Business (ICSB). Jej główne zainteresowania badawcze to aktywność innowacyjna MŚP, wspieranie MŚP oraz przedsiębiorczość kobiet.

Hanna Mizgajska, a full professor at the President Stanisław Wojciechowski State University of Applied Sciences in Kalisz, Faculty of Social Sciences and Humanities. She is an author of over 100 publications, mainly about economics and the functioning of SMEs, three of which are monographs. She also participated in several international conferences organised by the European Foundation for Management Development (EFMD) or the International Council for Small Business (ICSB). Her research areas include innovation activity of SMEs, supporting and developing SMEs and women entrepreneurship.

ORCID: 0000-0002-8997-9985 


\section{Adres/Address:}

Państwowa Wyższa Szkoła Zawodowa im. Prezydenta Stanisława Wojciechowskiego w Kaliszu Wydział Nauk Społecznych i Humanistycznych

ul. Nowy Świat 4a

62-800 Kalisz, Polska

e-mail: hanna.mizgajska@gmail.com

Łukasz Wściubiak, dr inż., adiunkt, Uniwersytet Ekonomiczny w Poznaniu, Instytut Zarządzania. Jego zainteresowania badawcze koncentrują się wokół zagadnień innowacji, współpracy międzyorganizacyjnej, zarządzania własnością intelektualną oraz przedsiębiorczości technologicznej. Jest członkiem European Council for Small Business and Entrepreneurschip (ECSB) oraz autorem ponad 30 artykułów opublikowanych w czasopismach naukowych, monografiach oraz materiałach konferencyjnych.

Łukasz Wściubiak, $\mathrm{PhD}$, an assistant professor, Poznan University of Economics and Business, Institute of Management. His research interests are focused on the issues of innovation, inter-organisational cooperation, intellectual property management and technology entrepreneurship. $\mathrm{He}$ is a member of the European Council for Small Business and Entrepreneurship (ECSB) and an author of over 30 papers released in scientific journals, monographs and conference proceedings.

ORCID: 0000-0003-3576-2323

\section{Adres/Address:}

Uniwersytet Ekonomiczny w Poznaniu

Instytut Zarządzania

al. Niepodległości 10

61-875 Poznań, Polska

e-mail: lukasz.wsciubiak@ue.poznan.pl 